\title{
PENGARUH MOTIVASI DAN DISIPLIN TERHADAP KINERJA GURU
}

\author{
Bahrudi Efendi Damanik \\ Manajemen Informatika, AMIK-STIKOM Tunas Bangsa Pematangsiantar \\ bahrudiefendi@gmail.com
}

\begin{abstract}
The purpose of this study was to determine the effect of motivation on teacher performance, the effect of discipline on teacher performance, the effect of motivation and discipline on teacher performance. The population in this study amounted to 44 people. The data analysis technique used in this research is descriptive analysis technique and multiple linear regression analysis. From the results of data processing, the following research results were obtained. The motivation variable partially has a positive effect on teacher performance with tcount> ttable (2.533> 1.684). Discipline variable partially has a positive effect on teacher performance with tcount $>$ ttable (5.931> 1.684). Motivation and discipline variables simultaneously have a positive effect on teacher performance with the value of Fcount> Ftable, namely 5.669> 3,230 ,. The influence of motivation and discipline variables on teacher performance is $72.20 \%$ and the remaining $28.80 \%$ is influenced by other factors not examined.
\end{abstract}

Keywords : Motivation, Discipline, Teacher Performance

\section{PENDAHULUAN}

Pendidikan dalam rangka menghasilkan Sumber Daya Manusia (SDM) yang berkualitas dan meningkatkan prestasi kerja bagi organisasi menempati posisi yang penting dan strategis. Pendidikan juga merupakan usaha sadar untuk menumbuh kembangkan potensi Sumber Daya Manusia (SDM) melalui kegiatan pengajaran. Kegiatan belajar mengajar melibatkan beberapa komponen, yaitu peserta didik, guru (pendidik), tujuan pembelajaran, isi pelajaran, metode mengajar, media dan evaluasi. Tujuan pembelajaran yang diinginkan tentu yang optimal. Hal ini sejalan dengan tujuan pendidikan yakni menyiapkan peserta didik menjadi anggota masyarakat yang memiliki kemampuan akademik dan profesional yang dapat menerapkan, mengembangkan dan atau memperkaya khasanah ilmu pengetahuan, teknologi dan kesenian. Menurut Rahardja (2004:4) bahwa kinerja adalah prestasi kerja atau hasil kerja. Kemampuan melaksanakan tugas atau kinerja (performance) adalah suatu hal yang dapat meningkatkan fungsi motivasi secara terus-menerus. Dengan demikian, kinerja guru adalah hasil kerja secara kualitas dan kuantitas yang dicapai oleh seorang guru dalam melaksanakan tugasnya sesuai dengan tanggung jawab yang diberikan kepadanya.

Menjadi guru tanpa motivasi kerja akan cepat merasa jenuh karena tidak adanya unsur pendorong. Motivasi mempersoalkan bagaimana caranya gairah kerja guru, agar guru mau bekerja 
keras dengan menyumbangkan segenap kemampuan, pikiran, keterampilan untuk mewujudkan tujuan pendidikan. Guru menjadi seorang pendidik karena adanya motivasi untuk mendidik. Bila tidak punya motivasi maka ia tidak akan berhasil untuk mendidik atau jika dia mengajar karena terpaksa saja karena tidak ada kemauan yang berasal dari dalam diri guru. Menurut Winardi (2000:17) "Motivasi merupakan suatu kekuatan potensial yang ada pada diri seseorang manusia, yang dapat dikembangkannya sendiri, atau dikembangkan oleh sejumlah kekuatan luar yang pada intinya sekitar imbalan moneter, dan imbalan non moneter, yang dapat mempengaruhi hasil kinerjanya secara positif atau negatif, itu semua tergantung pada situasi dan kondisi yang dihadapi orang yang bersangkutan".

Dengan demikian motivasi merupakan hal-hal yang menyebabkan, menyatukan, serta memperhatikan orang berperilaku tertentu. Motivasi mempunyai sifat yang tidak akan lepas dari sifat manusia itu sendiri dimana manusia secara individual kualitas diri yang berbeda-beda antara satu dengan yang lain. Motivasi menjadi aktualisasi seorang guru untuk meningkatkan kinerjanya, akan tetapi realitanya terdapat banyak guru yang kurang termotivasi, hal itu disebabkan kurang adanya persaingan antar guru. Guru mengajar hanya untuk memenuhi tuntutan atau kewajibannya dalam mengajar tanpa memperhatikan kemampuan siswa dalam memahami materi pembelajaran, sedangkan guru dituntut tidak hanya bisa mengajar saja tetapi juga harus bisa mendidik dan meningkatkan kompetensi dalam mengajar, sehingga tercipta persaingan antar guru untuk menjadi guru teladan dan berkompeten.
Disiplin juga menjadi salah satu faktor lain yang dapat meningkatkn kinerja. Menurut Fathoni (2006:172), "Disiplin adalah fungsi operatif manajemen Sumber Daya Manusia yang terpenting karena semakin baik disiplin karyawan atau guru, semakin bagus kinerjanya. Tanpa disiplin yang baik, sulit bagi organisasi mencapai hasil yang optimal. Kedisiplinan harus ditegakkan dalam suatu organisasi sekolah, karena tanpa dukungan disiplin karyawan yang baik, maka sulit untuk mewujudkan tujuannya".

Dilihat dari sudut pandang kedisiplinan kerja, pada realitanya terdapat guru yang masih kurang disiplin, hal itu terlihat dari datangnya guru ke sekolah tidak tepat waktu, dalam mengajar ada guru yang hanya memberikan tugas setelah itu hanya ditinggalkan begitu saja tanpa diawasi. Apa jadinya kalau suatu sekolah tidak menegakkan disiplin kerja, maka akan ada banyak guru atau karyawan yang sering membolos dan tidak mematuhi peraturan yang ada dalam sekolah tersebut. Sehingga itu akan berpengaruh terhadap hasil belajar siswa. Guru yang tidak disiplin akan membuat siswa menjadi malas dalam belajar sehingga kedepannya akan membuat prestasi belajar siswapun menjadi menurun. Seorang guru harus dapat melaksanakan tata tertib atau peraturan sekolah dengan baik, karena tata tertib yang berlaku merupakan aturan dalam ketentuan yang harus ditaati oleh siapapun demi kelancaran proses pendidikan yang ada dalam sekolah tersebut.

\section{Rumusan Masalah}

Rumusan masalah dalam penelitian ini adalah :
1. Bagaimana pengaruh motivasi terhadap kinerja guru 
2. Bagaimana pengaruh disiplin terhadap kinerja guru

3. Bagaimana pengaruh motivasi dan disiplin terhadap kinerja guru

\section{Tujuan Penelitian}

Tujuan dari penelitian ini adalah :

1. Untuk mengetahui pengaruh motivasi terhadap kinerja guru

2. Untuk mengetahui pengaruh disiplin terhadap kinerja guru

3. Untuk mengetahui pengaruh motivasi dan disiplin terhadap kinerja guru

\section{LANDASAN TEORI \\ Pengertian Motivasi}

Motif seringkali diistilahkan sebagai dorongan. Dorongan atau tenaga tersebut merupakan gerak jiwa dan jasmani untuk berbuat. Sehingga motif tersebut merupakan driving force yang menggerakkan manusia untuk bertingkah laku dan di dalam perbuatannya itu mempunyai tujuan tertentu (As'ad 2005 :

Motivasi secara sederhana dapat diartikan "Motivating" yang secara implisit berarti bahwa pimpinan suatu organisasi berada ditengah-tengah bawahannya, dengan demikian dapat memberikan bimbingan, instruksi, nasehat dan koreksi jika diperlukan (Siagian, 2005 : 129). Sedangkan pendapat lain mengatakan bahwa motivasi adalah keinginan yang terdapat pada seorang individu yang merangsang untuk melakukan tindakan. (Winardi,

$2002: 321$ ).

Motivasi adalah dorongan yang ada dalam diri manusia yang menyebabkan ia melakukan sesuatu (Wursanto, 2007:132). Dari berbagai pendapat diatas, dapat disimpulkan yaitu motivasi merupakan dorongan/daya yang timbul dari diri, tanpa ada paksaan dari siapapun untuk melakukan suatu pekerjaan.

\section{Disiplin Kerja}

Secara etimologi, disiplin berasal dari bahasa latin "disipel" yang berarti pengikut. Seiring dengan perkembangan jaman, kata tersebut mengalami perubahan menjadi "disipline" yang artinya kepatuhan atau yang menyangkut tata tertib. Disiplin kerja adalah suatu sikap ketaatan seseorang terhadap aturan/ketentuan yang berlaku dalam organisasi, yaitu : menggabungkan diri dalam organisasi itu atas dasar keinsafan, bukan unsur paksaan. (Wursnato, 2007 : 147).

Disiplin adalah sikap dari seseorang/kelompok orang yang senantiasa berkehendak untuk mengikuti/mematuhi segala aturan/keputusan yang ditetapkan. (M. Sinungan, 2000 : 135). Disiplin kerja adalah sikap mental yang tercermin dalam perbuatan atau tingkah laku seseorang, kelompok masyarakat berupa ketaatan (obedience) terhadap peraturan, norma yang berlaku dalam masyarakat. (Siagian 1996 : 145)

Menurut (Damanik, 2019) bahwa motivasi kerja guru adalah suatu perangsang keinginan dan daya gerak yang menyebabkan seorang guru bersemangat dalam mengajar karena terpenuhi dalam kebutuhannya.

Dari beberapa pendapat itu dapat disimpulkan bahwa disiplin kerja adalah sikap ketaatan dan kesetiaan seseorang/sekelompok orang terhadap peraturan tertulis/tidak tertulis yang tercermin dalam bentuk tingkah laku dan perbuatan pada suatu organisasi untuk mencapai suatu tujuan tertentu.

\section{Pengertian Kinerja Guru}

Keberhasilan suatu organisasi

dalam mencapai tujuan tergantung pada bagaimana para personel dalam melaksanakan pengajarannya sesuai 
dengan tugas dan tanggung jawabnya masing-masing. Dalam organisasi sekolah berhasil tidaknya tujuan pendidikan sangat ditentukan oleh kinerja guru. Karena tugas guru adalah mengelola kegiatan belajar mengajar.

Berkenaan dengan kinerja guru sebagai pengajar, menurut Uzer Usman (2005:16), mencakup aspek kemampuan personal, kemampuan profesional dan kemampuan sosial.

Kinerja adalah suatu hasil atau taraf kesuksesan yang dicapai oleh pekerja dalam bidang pekerjaannya, menurut kriteria tertentu yang berlaku untuk suatu pekerjaan tertentu dan dievaluasi oleh orang-orang tertentu (Damanik, 2019)

Performance diterjemahkan menjadi kinerja, juga berarti prestasi mengajar, pelaksanaan mengajar, pencapaian mengajar, hasil mengajar atau untuk mengajar (LAN, dalam Sedarmayanti, 2001:50). Menurut Fattah (2000:19), prestasi mengajar atau penampilan mengajar (performance) diartikan sebagai ungkapan kemampuan yang didasari oleh pengetahuan, sikap dan keterampilan dan motivasi dalam menghasilkan sesuatu. August W. Smith menyatakan kinerja adalah "output drive from processes, human or otherwise", jadi kinerja merupakan hasil atau keluaran dari suatu proses. (Sedarmayanti, 2001:50). Sedangkan menurut Mathis (2002:78), mengungkapkan bahwa kinerja pada dasarnya adalah apa yang dilakukan atau tidak dilakukan guru.

Berdasarkan uraian di atas dapat di simpulkan, kinerja adalah suatu hasil atau taraf kesuksesan yang dicapai oleh pengajar dalam bidang pengajarannya, menurut kriteria tertentu yang berlaku untuk suatu pengajaran tertentu dan dievaluasi oleh orang-orang tertentu.

Kinerja guru atau prestasi mengajar merupakan hasil yang dicapai oleh guru dalam melaksanakan tugas- tugas yang dibebankan kepadanya yang didasarkan atas kecakapan, kemudian pengalaman dan keunggulan serta penggunaan waktu. Kinerja guru akan baik jika guru telah melaksanakan unsur- unsur yang terdiri kesetian dan komitmen yang tinggi pada tugas mengajar. Kinerja guru dilihat dari sejauh mana guru tersebut melaksanakan tugasnya dengan tertib dan bertanggung jawab, kemampuan menggerakkan dan memotivasi siswa untuk belajar dan bekerjasama dengan guru lain.

\section{Kerangka Konseptual}

Untuk

mempermudah

pelaksanaan penulisan sekaligus

untuk mempermudah dalam penulisan agar tidak menyimpang dari inti permasalahan maka pelu dijelaskan suatu kerangka konseptual sebagai landasan dalam pembahasan. 


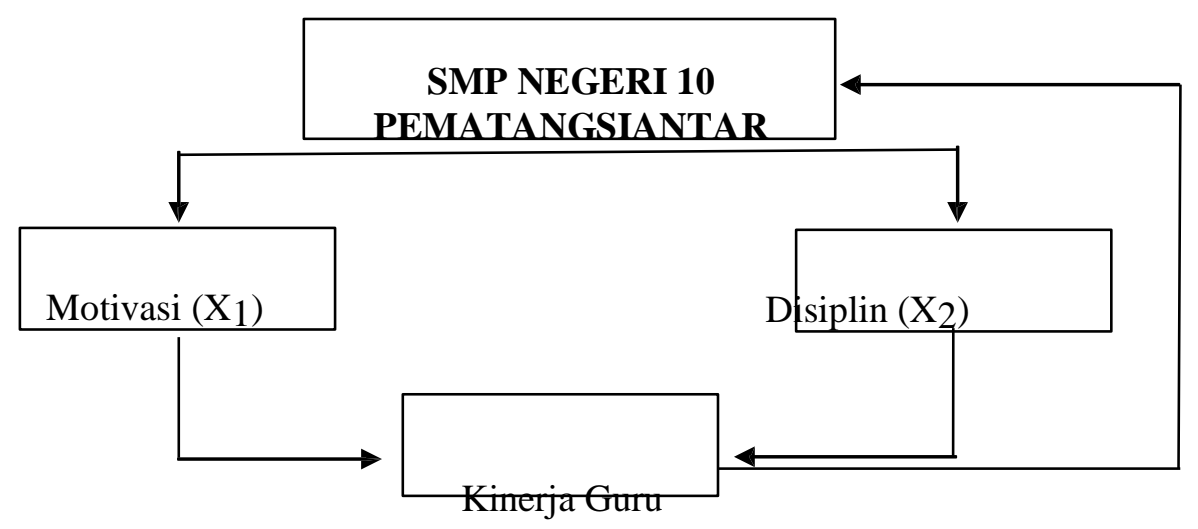

Gambar 1. Kerangka Konseptual

\section{Hipotesis}

Hipotesis adalah dugaan sementara dan masih harus diuji kebenarannya melalui penelitian. Dapat diartikan dengan asumsi/dugaan mengenai suatu hal yang dibuat untuk menjelaskan sesuatu yang sering dituntut untuk melakukan pengecekan (Sudjana, 2006 :

213). Hipotesis adalah jawaban sementara terhadap permasalahan penelitian, sampai terbukti melalui data yang terkumpul (Suharsimi Arikunto,

2006 : 83). Hipotesis dalam penelitian ini adalah :

1. Ada pengaruh positif dan signifikan antara motivasi terhadap kinerja guru

2. Ada pengaruh positif dan signifikan antara disiplin terhadap kinerja guru

3. Ada pengaruh positif dan signifikan antara motivasi dan disiplin terhadap kinerja guru

\section{METODE PENELITIAN}

\section{Lokasi penelitian dilakukan} dilakukan Sekolah Menengah Pertama (SMP) Negeri 10 Pematang Siantar. Jalan SM. Raja Komplek Rindam I/BB Pematang Siantar, yang jadi objek adalah "pengaruh motivasi dan disiplin terhadap kinerja guru".

Populasi dalam penelitian ini adalah seluruh guru di Sekolah
Menengah Pertama (SMP) Negeri 10 Pematang Siantar yang berjumlah 44 orang.

\section{Tehnik Pengumpulan Data.}

Tehnik Pengumpulan data dilakukan dengan cara :

1. Wawancara.

Peneliti melakukan wawancara langsung dan tidak langsung dengan pimpinan dan para guru di Sekolah Menengah Pertama (SMP) Negeri 10

Pematang Siantar yang dapat memberikan informasi yang berhubungan dengan objek penelitian agar diperoleh data yang diinginkan.

2. Kuisioner/Angket

Dengan memberikan daftar pertanyaan/angket sesuai dengan data yang diinginkan kepada responden yang berjumlah 44 orang guru.

3. Studi Perpustakaan.

Memperoleh data pendukung dalam penelitian berdasarkan pada buku- buku, literatur-literatur dan penelitianpenelitian sebelumnya yang relevan terhadap objek yang diteliti. 


\section{Tehknik Analisis Data}

Tehnik analisis data yang digunakan dalam penelitian ini adalah :

1. Tehnik Analisis Deskriptif.

Yaitu analisis yang digunakan untuk menganalisis data dengan cara mendeskripsikan atau menggambarkan data yang telah terkumpul sebagaimana adanya, tanpa

bermaksud membuat

kesimpulan yang berlaku untuk umum atau generalisasi.

2. Analisis Regresi Linier Berganda.

Rumus yang digunakan adalah

$\mathrm{Y}=\mathrm{a}+\mathrm{b} 1 \mathrm{X} 1+\mathrm{b} 2 \mathrm{X} 2+\mathrm{E}$

dimana

Y : Kinerja Guru a

: Konstanta

b : Koefisien regresi

X1 : Motivasi

X2 : Disiplin

E : Standard error

Dengan penggunaan teknik Analisis

Data Regresi Linier Berganda tersebut, maka formulasi hipotesis yang akan penulis tetapkan yaitu :

a. Uji Parsial (variabel $\mathrm{X}$ terhadap $\mathrm{Y}$ ) dengan rumus sebagai berikut:

$$
\text { Uji t } \square \frac{r \sqrt{n-2}}{\sqrt{1-r^{2}}}
$$

Dimana

$\mathrm{r}$ : Korelasi

$\mathrm{n}$ : Jumlah sampel

Jika thitung $>\mathrm{t}$ tabel : $\quad$ Ho ditolak

H1 diterima.
Jika t hitung $<\mathrm{t}$ tabel : $\quad$ Ho diterima

H1 ditolak

b. Uji Simultan (variabel X1 dan X2 terhadap $\mathrm{Y}$ ) dengan rumus sebagai berikut:

$$
\text { F hit }=\frac{R^{2}(n-m-1)}{M\left(1-R^{2}\right)}
$$

Dimana :

$$
\begin{array}{ll}
\mathrm{R} & =\text { Korelasi } \\
\mathrm{n} & =\text { Jumlah Sampel } \\
\mathrm{m} & =\text { Jumlah Variabel Bebas }
\end{array}
$$

Jika $\mathrm{F}$ hitung $>\mathrm{F}$ tabel, maka Ho ditolak H1 diterima.

Jika $\mathrm{F}$ hitung < F tabel, maka Ho diterima H1 ditolak

Untuk mengetahui pengaruh disiplin dan lingkungan kerja terhadap kepuasan guru-guru, akan dilakukan uji determinasi dengan rumus $D=r^{2} \times 100$

$\%$. Penelitian ini menggunakan tingkat kepercayaan $95 \%(\alpha=0,05)$ dan untuk memudahkan penulis dalam pengolahan data digunakan program SPSS versi 17.

\section{Hasil dan Pembahasan \\ Uji Hipotesis}

Selanjutnya dalam analisis data ini penulis akan melakukan pengujian hipotesis, baik secara partial ataupun secara simultan. Selanjutnya untuk mempermudah dalam analisis data ini, maka penulis mencari nilainilai yang dibutuhkan dengan menggunakan perangkat lunak komputer software SPSS versi 17 dengan hasil sebagai berikut :

Tabel 1. Descriptive Statistics

\begin{tabular}{|l|c|c|r|}
\hline & Mean & Std. & \\
Deviation & N \\
\hline Kinerja.Guru & 39.8636 & 4.44915 & 44 \\
Motivasi & 39.4773 & 2.44463 & 44 \\
Disiplin & 39.2500 & 4.39410 & 44 \\
\hline
\end{tabular}

Sumber : hasil pengolahan data tahun 2019 


\section{Pengaruh Motivasi Terhadap Kinerja Guru}

Untuk mengetahui secara partial pengaruh motivasi terhadap kinerja guru dapat dilihat pada tabel 2. dibawah ini.

Tabel 2. Coefficients

\begin{tabular}{|c|c|c|c|c|c|c|}
\hline \multirow[t]{2}{*}{ Model } & & \multicolumn{2}{|c|}{$\begin{array}{c}\text { Unstandardized } \\
\text { Coefficients }\end{array}$} & \multirow{2}{*}{$\begin{array}{c}\text { Standardized } \\
\text { Coefficients } \\
\text { Beta }\end{array}$} & \multirow[t]{2}{*}{$\mathrm{t}$} & \multirow[t]{2}{*}{ Sig. } \\
\hline & & B & $\begin{array}{l}\text { Std. } \\
\text { Error }\end{array}$ & & & \\
\hline 1 & $\begin{array}{l}\text { (Constant) } \\
\text { Motivasi }\end{array}$ & $\begin{array}{r}5.397 \\
.500\end{array}$ & $\begin{array}{r}6.066 \\
.197\end{array}$ & .274 & $\begin{array}{r}.890 \\
2.533\end{array}$ & $\begin{array}{l}.379 \\
.015\end{array}$ \\
\hline
\end{tabular}

a dependent variable: kinerja guru - Hasil pengolaha data-2019

Berdasarkan tabel 2. di atas diketahui pada tingkat kepercayaan $95 \%(\alpha: 0,05)$ bahwa nilai thitung variabel motivasi sebesar dengan $\mathrm{N}-2=44-2=42$ adalah 1.684 , 2.533 dan nilai signifikansi 0,015 , sedangkan sehingga dapat jabarkan pada gambar 2 . nilai t-tabel dibawah

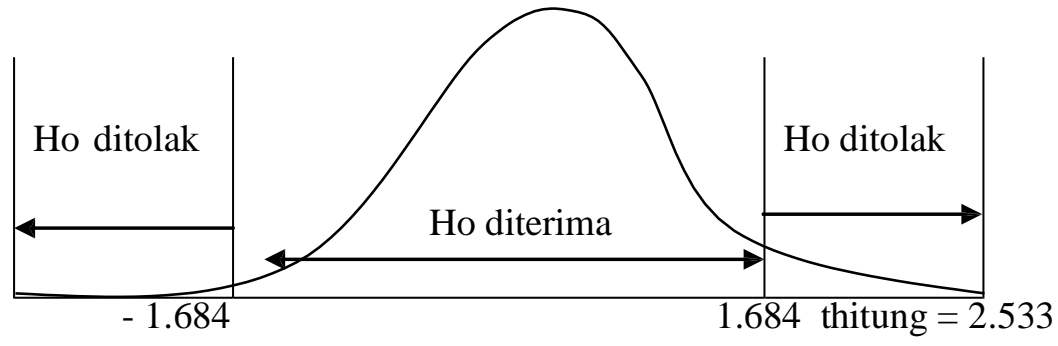

Gambar 2. Uji hipotesis motivasi terhadap kinerja guru

Dari Gambar 2. diatas diketahui bahwa nilai thitung > ttabel $(2.533>$ 1.684) maka diputuskan koefisien regresi signifikan atau $\mathrm{HO}$ ditolak dan menerima hipotesis dalam penelitian ini yaitu variabel motivasi secara partial berpengaruh positif dan signifikan terhadap kinerja guru di Sekolah Menengah Pertama (SMP) Negeri 10 Pematangsiantar. Hal ini dapat dibuktikan pula dari nilai Probabilitas $=0.000$; atau $\mathrm{P}$ $<0.05$; berarti koefisien regresi motivasi secara partial signifikan pada tingkat kepercayaan $95 \quad \% \quad(\alpha \quad: \quad 0,05)$.

\section{Pengaruh Disiplin Terhadap Kinerja Guru.}

Untuk mengetahui secara partial pengaruh disiplin terhadap kinerja guru dapat dilihat pada tabel 5.6 dibawah ini. 


\begin{tabular}{|c|c|c|c|c|c|c|}
\hline \multirow{2}{*}{ Model } & & \multicolumn{2}{|c|}{$\begin{array}{c}\text { Unstandardized } \\
\text { Coefficients }\end{array}$} & $\begin{array}{c}\text { Standardized } \\
\text { Coefficients }\end{array}$ & $\mathrm{t}$ & Sig. \\
& & $\mathrm{B}$ & $\begin{array}{c}\text { Std. } \\
\text { Error }\end{array}$ & Beta & & \\
\hline 1 & (Constant) & 5.397 & 6.066 & & .890 & .379 \\
\hline & Disiplin & .651 & .110 & .643 & 5.931 & .000 \\
\hline
\end{tabular}

a Dependent Variable: Kinerja.Guru - Hasil pengolaha data-2019

Berdasarkan tabel 3. di atas diketahui bahwa nilai thitung variabel disiplin sebesar 5.931 dan nilai signifikansi 0,000 , sedangkan nilai t-tabel pada tingkat kepercayaan $95 \%(\alpha: 0,05)$ dengan $\mathrm{N}-2=44-2=42$ adalah 1,684, sehingga dapat diperhatikan pada gambar 3.

dibawah

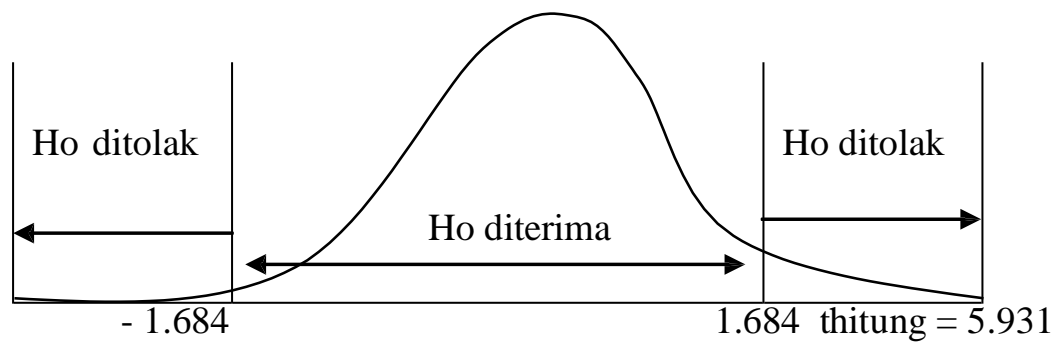

Gambar 3. Uji hipotesis disiplin terhadap kinerja guru

Dari Gambar 3. diatas diketahui bahwa nilai thitung > ttabel (5.931 > 1.684) maka diputuskan koefisien regresi signifikan atau $\mathrm{H} 0$ ditolak dan menerima hipotesis dalam penelitian ini yaitu variabel disiplin secara partial berpengaruh positif dan signifikan terhadap kinerja guru di Sekolah Menengah Pertama (SMP) Negeri 10 Pematangsiantar. Hal ini dapat dibuktikan pula dari nilai Probabilitas $=0.000$, atau $\mathrm{P}$ $<0.05$, berarti koefisien regresi variabel disiplin secara partial signifikan pada tingkat kepercayaan $\quad 95 \quad \% \quad(\alpha \quad: \quad 0,05)$

\section{Pengaruh Motivasi Dan Disiplin Terhadap Kinerja Guru}

Tabel 4. Model Summary

\begin{tabular}{|c|c|c|c|c|c|c|c|c|c|}
\hline \multirow[b]{2}{*}{$\begin{array}{l}\text { Mode } \\
1\end{array}$} & \multirow[b]{2}{*}{$\mathrm{R}$} & \multirow{2}{*}{$\begin{array}{l}\mathrm{R} \\
\text { Squa } \\
\text { re }\end{array}$} & \multirow[b]{2}{*}{$\begin{array}{l}\text { Adjusted } \\
\text { R Square }\end{array}$} & \multirow{2}{*}{$\begin{array}{l}\text { Std. Error } \\
\text { of the } \\
\text { Estimate }\end{array}$} & \multicolumn{5}{|c|}{ Change Statistics } \\
\hline & & & & & $\begin{array}{c}\mathrm{R} \\
\text { Square } \\
\text { Change }\end{array}$ & $\begin{array}{c}\mathrm{F} \\
\text { Change }\end{array}$ & df1 & df2 & $\begin{array}{c}\text { Sig. F } \\
\text { Change }\end{array}$ \\
\hline 1 & $.844(a)$ & .712 & .698 & 2.44541 & .712 & 50.669 & 2 & 41 & .000 \\
\hline
\end{tabular}

a Predictors: (Constant), .Disiplin, .Motivasi b

Dependent Variable: Kinerja.Guru

Hasil pengolaha data-2019

Dari tabel 4. diatas diketahui bahwa nilai korelasi secara simultan

antara motivasi dan manajemen bernasis sekolah terhadap kinerja guru di 
Sekolah Menengah Pertama (SMP) Negeri 10 Pematangsiantar sebesar 0,712 . Nilai korelasi ini dapat dikategorikan pada korelasi yang kuat karena berada pada interval $(0,60-0.80)$. Kemudian untuk membuktikan kebenaran hipotesis penelitian atau apakah nilai korelasi itu dapat digeneralisasikan, maka harus diuji signifikasinya dengan uji-F, dan dari pengolahan data diketahui nilai Fhitung sebesar 50.669. Nilai F-hitung ini selanjutnya diinterpretasikan dengan nilai Ftabel dan dengan tingkat kpercayaan $95 \%(\square=0,05)$, dengan $\mathrm{dk}$ pembilang $=\mathrm{k}$ dan dk penyebut $=44-2=42$, maka nilai Ftabel $=3,230$. Jadi dari hasil perhitungan uji signifikan, dapat dilihat bahwa nilai Fhitung > Ftabel yaitu 5.669

$>3,230$, jadi hipotesis penelitian secara simultan dapat dibuktikan yaitu terdapat pengaruh positif dan signifikan antara disiplin terhadap kinerja guru di Sekolah Menengah Pertama (SMP) Negeri 10

Pematangsiantar.
Selanjutnya untuk mengetahui seberapa besar pengaruh motivasi dan disiplin terhadap kinerja guru, maka diuji dengan uji determinan (D). Dari pengolahan data diperoleh nilai $\mathrm{r}^{2}$ (Rsquare) sebesar 0.712, maka dapat diketahui nilai Determinannya adalah

$0,712 \times 100 \%=71,20 \%$, yang berarti bahwa variabel motivasi dan disiplin

secara simultan berpengaruh positif dan signifikan terhadap kinerja guru sebesar $71.20 \%$, dan sisanya sebesar $28.80 \%$ dipengaruhi oleh faktor-faktor lain yang tidak diteliti atau tidak dimasukkan dalam model penelitian ini.

\section{Analisis Regresi Linier Berganda}

Analisis regresi linier berganda ini digunakan untuk mengestimasi pengaruh variabel motivasi dan disiplin terhadap kinerja guru di Sekolah Menengah Pertama (SMP) Negeri 10

Pematangsiantar. Berdasarkan hasil pengolahan data diperoleh hasil sebagai berikut:

\section{Tabel 5. Hasil Uji Signifikansi Variabel Independent Coefficients(a)}

\begin{tabular}{|c|c|c|c|c|c|c|}
\hline \multirow[t]{2}{*}{$\begin{array}{l}\text { Mode } \\
1\end{array}$} & & \multicolumn{2}{|c|}{$\begin{array}{l}\text { Unstandardized } \\
\text { Coefficients }\end{array}$} & $\begin{array}{l}\text { Standardized } \\
\text { Coefficients }\end{array}$ & \multirow[t]{2}{*}{$\mathrm{t}$} & \multirow[t]{2}{*}{ Sig. } \\
\hline & & & & & & \\
\hline \multirow[t]{3}{*}{1} & (Constant) & 5.397 & 6.066 & & .890 & .379 \\
\hline & .Motivasi & .500 & . 197 & 274 & 2.533 & .015 \\
\hline & .Disiplin & .651 & . 110 & .643 & 5.931 & .000 \\
\hline
\end{tabular}

a Dependent Variable: Kinerja.Guru

Hasil pengolaha data-2019

Berdasarkan pada tabel 5. diatas, persamaan regresi linier berganda adalah sebagai berikut :

$\mathrm{Y}=\mathbf{5 . 3 9 7}+0.500 \mathrm{X} 1+0.651 \mathrm{X} 2+\varepsilon$

Dengan persamaan regresi linier berganda tersebut dapat dijelaskan bahwa
1. Nilai konstanta adalah sebesar 5.397, hal ini menyatakan bahwa jika faktor motivasi dan disiplin diabaikan maka nilai kinerja guru sebesar 5.397.

2. Koefisien regresi untuk variabel motivasi $\begin{array}{lll}\text { sebesar } & 0.500 \quad \text { menunjukkan }\end{array}$ 
bahwa setiap kenaikkan $1 \%$ faktor motivasi maka akan meningkatkan kinerja guru sebesar 5\%.

3. Koefisien regresi untuk variabel disiplin sebesar 0,651, hal menunjukkan bahwa setiap kenaikkan

$1 \%$ faktor disiplin maka kinerja guru akan meningkat sebesar $6.51 \%$.

Berdasarkan pada persamaan regresi berganda diatas, dapat disimpulkan bahwa motivasi dan disiplin ditingkatkan maka kinerja guru juga akan meningkat, begitu juga sebaliknya jika variabel motivasi dan disiplin mengalami penurunan maka akan menurunkan kinerja guru di Sekolah Menengah Pertama (SMP) Negeri 10 Pematangsiantar.

\section{Pembahasan}

Berdasarkan hasil analisis data diketahui bahwa variabel bebas pertama yakni motivasi di Sekolah Menengah Pertama (SMP) Negeri 10 Pematangsiantar dikategorikan cukup baik, oleh karena itu kepala sekolah sebaiknya selalu memotivasi para guru agar bersedia bekerja demi sasaran- sasaran tingkat tinggi yang hendak dicapai, pimpinan agar membuat ide-ide atau terobosan ke arah yang lebih baik dan relevan, tindakan pimpinan dalam menghadapi suatu masalah dan persoalan diharapkan cukup tegas, pimpinan memberikan pujian kepada bawahan yang berprestasi, pimpinan mengikut sertakan bawahan dalam pengambilan keputusan, pimpinan mengajak bawahan untuk berfikir ke arah dengan caracara baru.

Variabel disiplin dikategorikan cukup baik, hal ini disebabkan pimpinan sering mengontrol apa yang telah dilaksanakan untuk mencapai kepastian bahwa pekerjaan berlangsung dengan memuaskan kearah pencapaian sasaran yang telah ditetapkan.

Kinerja guru dikategorikan baik, hal ini digambarkan karena penggajian guru adalah berdasarkan pendidikan dan pengalaman, kadang ada upah/gaji lain seperti upah lembur yang diberikan, guru merasa keamanan terjamin dalam melaksanakan tugas, adanya tunjangan kesehatan diberikan kepada guru yang sakit.

Hal ini memberi gambaran bahwa apabila motivasi dan disiplin ditingkatkan akan meningkatkan kinerja guru. Besar pengaruh variabel motivasi dan disiplin terhadap kinerja guru sebesar $71.20 \%$ berarti sissanya sebesar $28.80 \%$ dipengaruhi faktor lain yang tidak diteliti.

\section{Kesimpulan}

1. Variabel motivasi secara partial berpengaruh positif terhadap kinerja guru dengan nilai thitung > ttabel $(2.533>$ 1.684).

2. Variabel disiplin secara partial berpengaruh positif terhadap kinerja guru dengan nilai thitung > ttabel (5.931> 1.684)

3. Variabel motivasi dan disiplin secara simultan berpengaruh positif terhadap kinerja guru dengan nilai Fhitung > Ftabel yaitu $5.669>3,230$,

4. Besar pengaruh variabel motivasi dan disiplin terhadap kinerja guru sebesar $72.20 \%$ dan sisanya sebesar $28.80 \%$ dipengaruhi faktor lain yang tidak diteliti.

\section{Saran}

1. Berdasarkan hasil penelitian bahwa kedua variabel bebas yaitu motivasi dan disiplin mempunyai pengaruh positif dan signifikan terhadap kinerja guru di Sekolah Menengah Pertama (SMP) Negeri $10 \quad$ Pematangsiantar, oleh karena itu dapat kiranya 
dipertahankan dan jika memungkinkan untuk ditingkatkan sehingga kinerja guru akan ikut meningkat juga.

2. Kepada guru kiranya dapat meningkatkan kualitas SDM nya

\section{DAFTAR PUSTAKA}

Arikunto, Suharsimi. 2002. Prosedur Penelitian Suatu Pendekatan Praktek. Jakarta : Pt. Rhineka. Cipta

Damanik, B. E. (2019). Pengaruh Kepemimpinan dan Iklim Kerja Terhadap Semangat Kerja Guru. Ciencias: Jurnal Penelitian Dan Pengembangan Pendidikan, 2(2), 101-109.

Damanik, B. E. (2019). Pengaruh motivasi dan komitmen terhadap peningkatan prestasi kerja guru. $E K$ \& BI, 2(1), 3 .

GR. Terry, 2003. Pengembangan Sumber Daya Manusia. Yogyakarta : Liberty.

Hani Handoko, 2000. Manajemen Sumber Daya Manusia. Jakarta ; Ghalia Indonesia.

Kaplan, Robert M., and Denis P Saccuzzo, 2003., Phychological Testing (Principles, Aplication, and Issues), 3rd Edition Books, Cole Publishing Company, California.

Malayu SP. Hasibuan, 2006. Organisasi dan Motivasi Dasar Peningkatan Produktifitas, Bandung : Bina Aksara.

Moch. As'ad, 2005. Psikologi Industri. Jakarta : Liberty.

Muchdarsyah Sinungan, 2000. Produktifitas, Apa dan Bagaimana. Jakarta : Bumi Aksara.

Saifuddin Azwar, 2007., Relabilitas dan Validitas, Pustaka Pelajar Offset, Yogyakarta.

Soejono, 2007. Sistem dan Prosedur Kerja. Jakarta : Bumi Aksara. dengan mengikuti pendidikan dan pelatihan atau melanjutkan studi ke jenjang yang lebih tinggi lagi dari yang sekarang.

Sondang P. Siagian, 2005. Organisasi Kepemipinan Perilaku Administrasi. Jakarta : Gunung Agung.

Sudjana, 2006. Metode Statistika. Bandung : Tarsito.

Sugiyono, 2000. Statistika Untuk Penelitian. Bandung: Alfabeta.

Suharsimi Arikunto, 2006. Prosedur Penelitian Suatu Pendekatan Praktek. Jakarta : Rineka Cipta. Susilo

Martoyo, 2002. Manajemen Sumber Daya Manusia. Jakarta : BPFE.

Sutrisno Hadi, 2005. Metodologi Penelitian. Jakarta : Rajawali. Winardi, 2000, Kepemimpinan Dalam Manajemen. Jakarta : Rineka Cipta. Wursanto, 2007. Manajemen Keguruan. Yogyakarta : Kanisius. 